Article

\title{
Low-Cost and Eco-Friendly Hydroxyapatite Nanoparticles Derived from Eggshell Waste for Cephalexin Removal
}

\author{
Huda S. Alhasan ${ }^{1}\left(\mathbb{D}\right.$, Nadiyah Alahmadi $^{2}$, Suhad A. Yasin ${ }^{3}\left(\mathbb{D}\right.$, Mohammed Y. Khalaf $^{3}$ and Gomaa A. M. Ali ${ }^{4, *(D)}$ \\ 1 Environmental Research and Studies Center, University of Babylon, Hilla 51002, Iraq; \\ sci.huda.s@uobabylon.edu.iq \\ 2 Department of Chemistry, College of Science, University of Jeddah, Jeddah 21959, Saudi Arabia; \\ nalahmadi@uj.edu.sa \\ 3 Department of Chemistry, College of Science, University of Duhok, Duhok 42001, Iraq; \\ suhad.yasin@uod.ac (S.A.Y.); mohammed.khalaf@uod.ac (M.Y.K.) \\ 4 Chemistry Department, Faculty of Science, Al-Azhar University, Assiut 71524, Egypt \\ * Correspondence: gomaasanad@azhar.edu.eg
}

Citation: Alhasan, H.S.; Alahmadi, N.; Yasin, S.A.; Khalaf, M.Y.; Ali, G.A.M. Low-Cost and Eco-Friendly Hydroxyapatite Nanoparticles Derived from Eggshell Waste for Cephalexin Removal. Separations 2022, 9, 10. https://doi.org/ 10.3390/separations 9010010

Academic Editor: Hongbin Pu

Received: 6 December 2021

Accepted: 30 December 2021

Published: 5 January 2022

Publisher's Note: MDPI stays neutral with regard to jurisdictional claims in published maps and institutional affiliations.

Copyright: (c) 2022 by the authors. Licensee MDPI, Basel, Switzerland. This article is an open access article distributed under the terms and conditions of the Creative Commons Attribution (CC BY) license (https:// creativecommons.org/licenses/by/ $4.0 /)$.

\begin{abstract}
This work describes the hydroxyapatite nanoparticle (HAP) preparation from eggshell waste and their application as an adsorbent for Cephalexin (Ceph) antibiotic removal from aqueous solutions. Chemical precipitation with phosphoric acid was used to evaluate the feasibility of calcium oxide for HAP preparation. The structural properties of HAP were characterized by X-ray diffraction, which revealed the formation of the hydroxyapatite crystalline phase formation. In addition, transmitting electron spectroscopy showed an irregular shape with a variation in size. The impact of various experimental conditions on the removal efficiency such as the solution's $\mathrm{pH}$, contact time, HAP mass, solution temperature, and Ceph concentration were studied. Experimental data showed that HAP could remove most Ceph species from aqueous solutions within $1 \mathrm{~h}$ at $\mathrm{pH}=7$ with $70.70 \%$ adsorption efficiency utilizing $50 \mathrm{mg}$ of the HAP. The removal process of Ceph species by HAP was kinetically investigated using various kinetic models, and the results showed the suitability of the pseudo-second-order kinetic model for the adsorption process description. Moreover, the removal process was thermodynamically investigated; the results showed that the removal was spontaneous endothermic and related to the randomness increase. The data confirmed that HAP had high efficiency in removing Ceph antibiotics from an aqueous solution.
\end{abstract}

Keywords: hydroxyapatite; nanoparticles; eggshell waste; Cephalexin; adsorption

\section{Introduction}

Recently, pharmaceutical pollution of aquatic environments has been regarded as a serious global issue [1,2]. Various methods including municipal medical and industrial wastewater effluents release pharmaceutical medications into the aquatic environment [3]. Since these pharmaceuticals persist in the environment for long periods due to their continuous discharge, they are remarkably resistant to biodegradation processes, raising concerns about their long-term impact on human health. Cephalexin (Ceph) belongs to the first generation of antimicrobials (cephalosporins) [4] that have been used to treat a wide variety of human diseases caused by both Gram-negative and Gram-positive bacteria [5]. The continuous presence of Ceph in the aquatic environment poses several significant environmental hazards and serious health issues [6].

Furthermore, antibiotics disposed in the environment from various sources are widely regarded as serious dangers to human health due to their critical role in spreading antimicrobial resistance [7]. Ceph was selected as an adsorbate in the present work due to the widespread use of its respective antibiotic families. Consequently, removing antibiotics including Ceph before discharging wastewater is essential. 
Various approaches have been adopted to remove Ceph from an aqueous solution such as liquid membrane separation, solid-phase extraction, bioaugmentation, catalytic ozonation, nanofiltration, sonochemical degradation, and adsorption [8-11]. To date, adsorption is still an effective method to treat antibiotic pollutants from the aqueous solution because of its simplicity of design, low-cost process, ease of operation [12,13], and the absence of reaction with pollutants or toxic compounds [14,15]. Consequently, various natural and synthetic materials have been studied for Ceph adsorption including activated carbon, clay, zeolite, and different nanomaterials [16,17]. Nanoparticles are efficient materials for Ceph removal that can be utilized as adsorbents, photocatalysts, and membrane materials [18]. Physical and chemical approaches are used to design and produce nanostructures [19].

In the past years, the green synthesis of nanoparticles has acquired attention as a cost-effective and ecologically friendly alternative to physical and chemical processes [20]. The ability to generate a usable product from bio-based waste would significantly improve and ensure global economic development along with waste management issues [21-23]. To achieve this criterion, bio-based ceramic development has been widely promoted for industry and academic studies, which have identified a ceramic produced from naturally occurring resources $[24,25]$. One of the most effective bio-based ceramics is hydroxyapatite (HAP) $\mathrm{Ca}_{10}\left(\mathrm{PO}_{4}\right)_{6}(\mathrm{OH})_{2}$. HAP has been widely considered as an adsorbent for various applications due to its biocompatibility, environmental friendliness, high sorption efficiency for heavy metals, low solubility in water, excellent stability under reduced and oxidized processes, and large surface area [26-28]. Obtaining low-cost adsorbents is highly required, therefore, many studies have reported nanosorbent preparation from waste precursors including palm kernel shells, eggshells, rice hulls, agricultural, electronic, and industrial wastes [29-32]. HAP can be derived from fish scales, animal bones, coral, and eggshells [33,34]. Eggshell is a relatively economical and widely accessible natural resource used as a raw material in producing HAP, a natural porous bioceramic with a calcium carbonate content of 97\% [35]. Eggshell can be derived into calcium carbonate in calcite and then converted to HAP in a hydrothermal reaction using a source of phosphate solution such as phosphoric acid and diammonium hydrogen phosphate [36]. In this study, eggshell was recycled to synthesize HAP. The physical and chemical characteristics of the obtained material were investigated. So far, if any, there are no detailed studies on preparing HAP from eggshell waste and using it for Ceph removal. Thus, this work deals with the potential use of HAP to eliminate the Ceph antibiotic from an aqueous solution.

\section{Experimental}

\subsection{Reagents and Materials}

Chicken eggshell waste has been collected as primary raw material from home. Ceph $\left(\mathrm{C}_{16} \mathrm{H}_{17} \mathrm{~N}_{3} \mathrm{O}_{4} \mathrm{~S} ; \mathrm{M} . W \mathrm{t} .347 .39 \mathrm{~g} / \mathrm{mol}\right)$ was purchased from the state company for the drug industries in Samarra/Iraq. All other chemicals (phosphoric acid $\left(\mathrm{H}_{3} \mathrm{PO}_{4}\right)$, ammonium hydroxide $\left(\mathrm{NH}_{4} \mathrm{OH}\right)$ ) were purchased from Sigma-Aldrich and utilized as received with no additional purifications. The stock solution of Ceph $(100 \mu \mathrm{g} / \mathrm{mL})$ was produced by dissolving the required amount in deionized water, and standard solutions $(5-70 \mathrm{~g} / \mathrm{mL})$ were produced by diluting the stock solution with deionized water. After calibrating the $\mathrm{pH}$ meter with buffer solutions 4,7 , and 10 , its value was adjusted utilizing $(0.1 \mathrm{~mol} / \mathrm{L})$ $\mathrm{HNO}_{3}$ and/or $(0.1 \mathrm{~mol} / \mathrm{L}) \mathrm{NaOH}$.

\subsection{Characterization Techniques and Apparatus}

The crystalline phase of HAP was determined using Siemens D5000 XRD fitted by $\mathrm{Cu}-\mathrm{K}_{\alpha}(\lambda=0.154 \mathrm{~nm})$. TEM (JEM $2011 \mathrm{JEOL}$, Tokyo, Japan), running at $200 \mathrm{kV}$, has been used to evaluate the size and shape of HAP. Samples were dispersed in ethanol and then ultrasonicated for $30 \mathrm{~min}$. After that, they were picked up using a carbon-coated copper grid (200 mesh) for the TEM characterizations. A Jenway UV-Vis (190-1100 nm) spectrophotometer (6800, Bibby Scientific, Stafford, UK) with a $10 \mathrm{~mm}$ (path width) quartz 
cell was used to record all the spectrophotometric measurements. A Hanna pH meter (301 models) was utilized for optimal solutions. The deionized water was obtained from the Milli-Q Plus system (Millipore, Bedford, MA, USA) and used to prepare all solutions.

\subsection{Preparation of HAP Nanoparticles from Eggshells}

To produce HAP, calcined eggshells were utilized as a calcium source, and phosphoric acid, 97\% (Sigma-Aldrich, St. Louis, MO, USA), was used as phosphate sources. Eggshell waste was collected first and then cleaned in deionized water (DI). After that, it was dried for $24 \mathrm{~h}$ in an oven at $100{ }^{\circ} \mathrm{C}$ to eliminate the contaminants and odor. It was milled and pressed through a $350 \mu \mathrm{m}$ sieve. Afterward, they were calcined in a furnace at a temperature of $900{ }^{\circ} \mathrm{C}$ for $3 \mathrm{~h}$ at a $10{ }^{\circ} \mathrm{C} / \mathrm{min}$ heating rate. Throughout this process, the organic matter is decomposed, and calcium carbonate $\left(\mathrm{CaCO}_{3}\right)$ is converted to calcium oxide $(\mathrm{CaO})$ through the release of carbon dioxide $\left(\mathrm{CO}_{2}\right)$ [37]. $\mathrm{CaO}$ powder was weighted and mixed with double-distilled water to form a $0.3 \mathrm{M}$ suspension, which then reacted with $\mathrm{H}_{3} \mathrm{PO}_{4}$ using a wet chemical precipitation process. During the reaction, $\mathrm{CaO}$ was suspended into $\mathrm{H}_{2} \mathrm{O}$, and $\mathrm{H}_{3} \mathrm{PO}_{4}$ was added dropwise to the solution, and the molar ratio of $\mathrm{Ca} / \mathrm{P}$ was estimated to be $2: 1$. The $\mathrm{pH}$ of the solution was adjusted to approximately 10 using $\mathrm{NH}_{4} \mathrm{OH}$. The reaction was magnetically mixed at $120^{\circ} \mathrm{C}$ for $6 \mathrm{~h}$ to obtain a homogenous suspension solution. Afterward, the suspension was filtered and then washed by DI before drying in the oven at $100{ }^{\circ} \mathrm{C}$ for $24 \mathrm{~h}$. After that, the dried product was heated at $900{ }^{\circ} \mathrm{C}$ for $2 \mathrm{~h}$. In the last step, the powder was milled and pressed through a sieve with a mesh size of $0.350 \mathrm{~mm}$ to collect the uniform particles before checking the purity; the whole procedure is illustrated in Figure 1 [38,39].

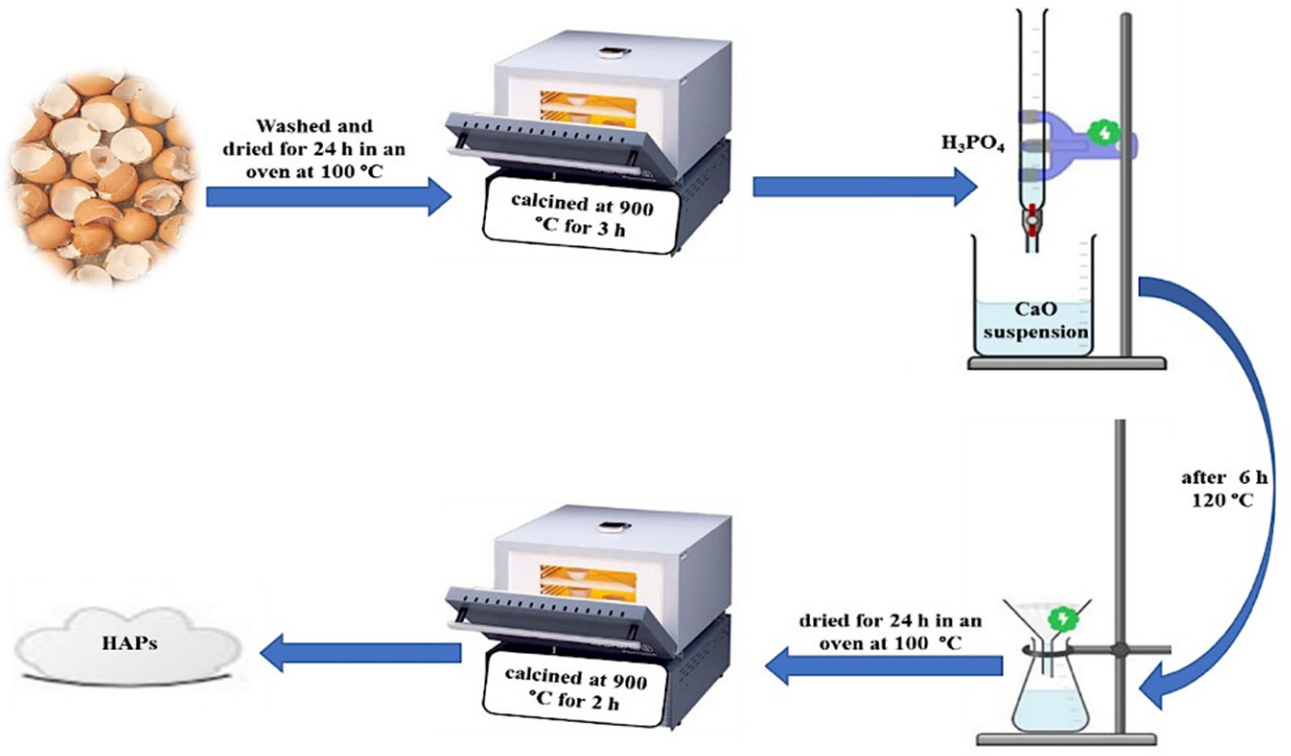

Figure 1. The schematic diagram of HAP synthesis.

\subsection{Step of Batch Extraction}

The exact weight $(0.05 \pm 0.002 \mathrm{~g})$ of the HAP solid phase was balanced with an aqueous solution $(25 \mathrm{~mL})$ consisting of Ceph $(10 \mathrm{mg} / \mathrm{L})$ at $\mathrm{pH}=7$. The samples were shaken for $60 \mathrm{~min}$ on a mechanical shaker. After that, the aqueous layer was broken up, and then the amount of Ceph remaining in the aqueous phase was photometrically determined. After equilibrium, the aqueous solution was separated, and the amount of Ceph remaining in the solution was measured using a UV-Vis spectrophotometer by measuring the absorbance of Ceph in the aqueous phase before and after the extraction at a wavelength of $261 \pm 2 \mathrm{~nm}$. Finally, the 
removal efficiency $(\mathrm{R}, \%)$ is expressed as Equation $(1)$, and the amount of Ceph adsorbed $\left(\mathrm{q}_{\mathrm{t}}\right)$ per unit mass of HAP solid phase is expressed as Equation (2), as follows [40-43]:

$$
\begin{gathered}
R(\%)=\frac{C_{o}-C_{t}}{C_{o}} \times 100 \\
q_{t}=\frac{\left(C_{o}-C_{t}\right) V}{m}
\end{gathered}
$$

where $C_{o}$ represents initial Ceph concentration and $C_{t}$ represents the remaining concentration of Ceph in the solution after shaking. In addition, the models' accuracy was confirmed using the regression coefficient $\left(\mathrm{R}^{2}\right)$, mean square error (MSE), root mean square error (RMSE), and average absolute relative deviation percent (AARD\%), according to the equations reported elsewhere [44].

\section{Results and Discussions}

\subsection{Characterizations of HAP}

The raw eggshell showed patterns consistent with $\mathrm{CaCO}_{3}$, and $\mathrm{CaO}$ was detected in the calcined eggshell. The peaks of the calcined eggshell powder indicated that $\mathrm{CaCO}_{3}$ were entirely decomposed and converted into $\mathrm{CaO}$ at approximately $900{ }^{\circ} \mathrm{C}$, as seen in the inset of Figure 2. It was seen that the five peaks at a Bragg angle of $32.1^{\circ}, 37.3^{\circ}, 53.8^{\circ}, 64.1^{\circ}$, and $67.3^{\circ}$ can be attributed to crystallographic planes of the cubic (fm-3m) crystals of $\mathrm{CaO}$. Those peaks were in agreement with $\mathrm{CaO}$ peaks (JCPDS card no. 00-004-0777) [45]; no other peaks due to the presence of other materials were observed. The resulting powder color changed from white into grey throughout the organic matter extrusion and subsequently into white. Therefore, snow-white powder obtained from the eggshells was $\mathrm{CaO}$. $\mathrm{CaO}$ thermal processing in phosphate solution formed a nanocrystalline white powder, irregular diameters, and high mechanical strength. Figure 2 illustrates the XRD pattern of the synthesized HAP powder at $900{ }^{\circ} \mathrm{C}$. As can be seen from Figure 2, observed planes were under the expected HAP pattern with a hexagonal structure (P63/m) (JCPDS No: 01-0759526) [46]. Therefore, a complete HAP synthesis was carried out based on the stoichiometric ratio of $\mathrm{Ca} / \mathrm{P}=1.67$.

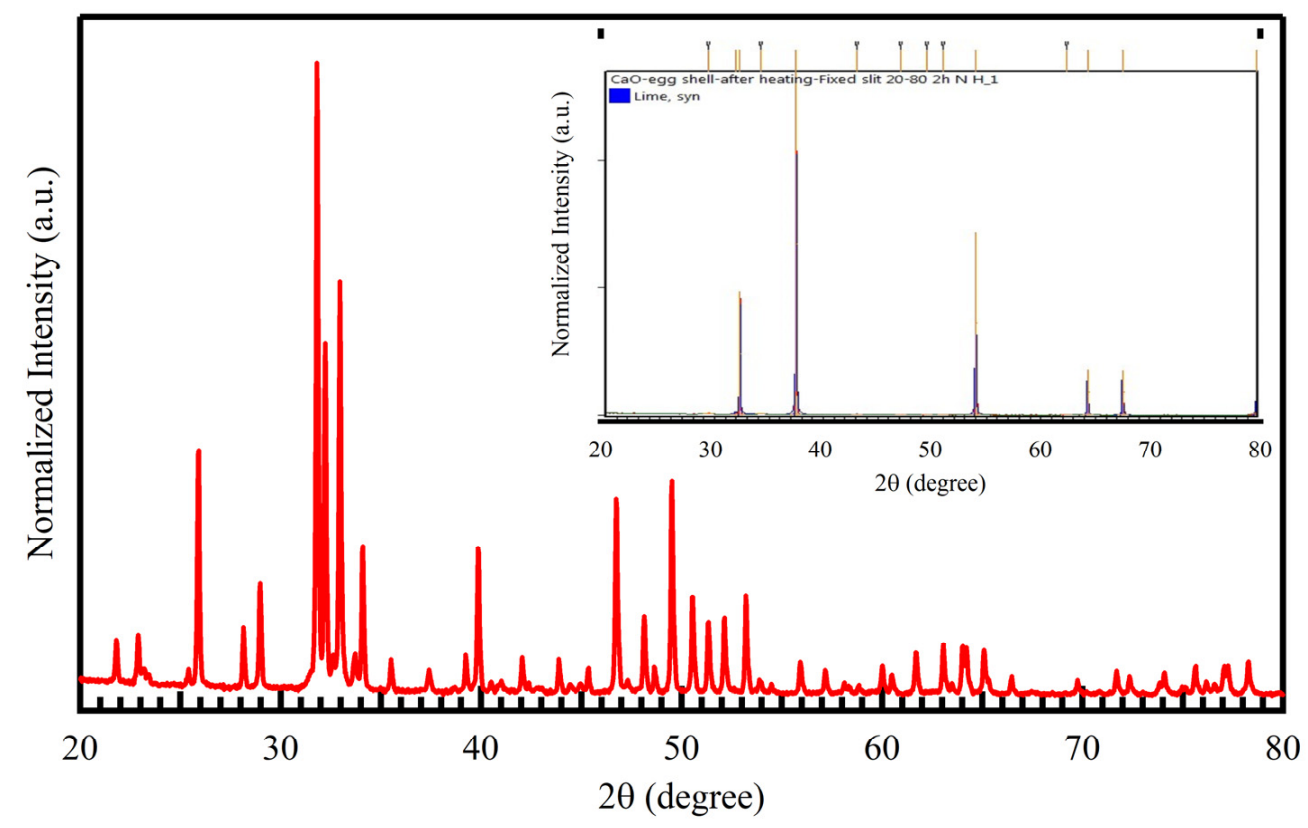

Figure 2. XRD patterns of synthesized HAP from eggshell waste. 
Figure 3 reveals the TEM image of the powder's HAP nanoparticles formed by agglomerates of spherical particles with a size of $100 \mathrm{~nm}$. Therefore, HAP nanocrystals produced in this work have a compatible size with the natural materials of the bone.

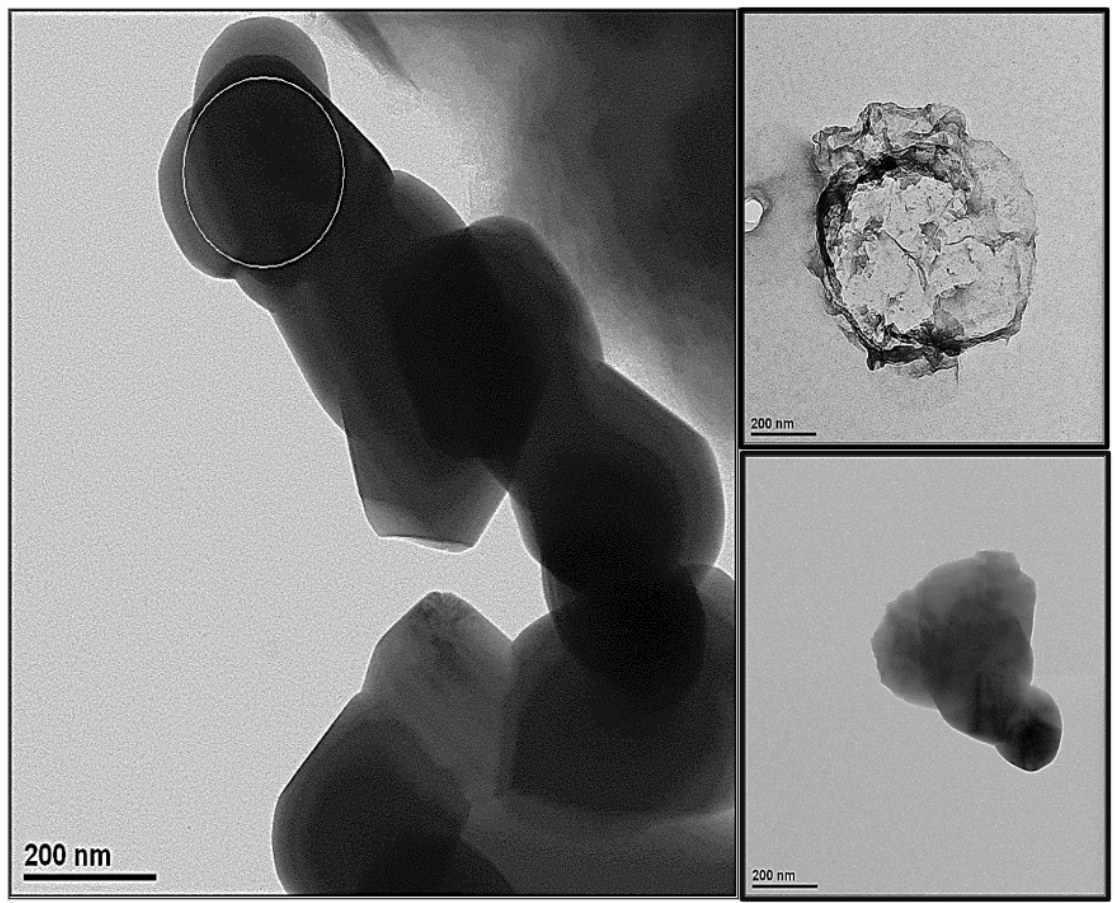

Figure 3. TEM images of hydroxyapatite derived from eggshell waste.

\subsection{Batch Adsorption Studies}

\subsubsection{Retention Profile of Ceph from Aqueous Solution onto HAP}

The solution $\mathrm{pH}$ is one of the essential parameters for achieving adsorption and recovery of heavy metal ions, dyes, and antibiotics. The sorption profile of aqueous solutions containing Ceph at various $\mathrm{pH}$ values by HAP solid phase was studied critically after shaking for $120 \mathrm{~min}$ at room temperature. The amount of Ceph in the aqueous phase following the equilibrium was photometrically determined [47]. The sorption percentage of Ceph sorption onto HAP increased noticeably with the increase in the $\mathrm{pH}$ of the solution to $\mathrm{pH}=7$. After that, the percentage decreased with the $\mathrm{pH}$ increase; representative data are shown in Figure 4a. Thus, pH 7 was chosen as an optimal value in the subsequent study.

The mass effect of HAP on Ceph adsorption from a $10 \mathrm{mg} / \mathrm{L}$ aqueous solution is shown in Figure $4 \mathrm{~b}$. It shows that the percentage that was removed from the aqueous solution was increased from 62.3 to $90.6 \%$ as the HAP dose increased from 25 to $250 \mathrm{mg}$.

The contact time between the adsorbent and adsorbate is a key factor in removing any pollutants from the environment through adsorption. The effects of contact time on removing Ceph by HAP were investigated, and the results are illustrated in Figure 4c. The figure shows that the increase in contact time increased in the adsorption process. This effect was particularly observed during the first $60 \mathrm{~min}$, where the majority of the Ceph was adsorbed. The percentage of Ceph removal reached equilibrium within $100 \mathrm{~min}$. This indicates that the adsorption of Ceph on HAP occurred in two successive steps: the first was the fastest, which transferred Ceph species from the aqueous phase to the external surface of HAP, while the second was the slower step, in which Ceph species diffuse between HAP bundles. Additionally, the effects of the temperature on the adsorption process were studied. Four different temperatures $(293,303,313$, and $323 \mathrm{~K})$ were tested at constant shaking time. It was noted that the significant increase in the temperature of the solution from 293 to $323 \mathrm{~K}$ is related to a considerable increase in the Ceph removal ratio, as seen in Figure $4 \mathrm{~d}$. These results suggest an endothermic nature of this process of adsorption. 
The Ceph profile of retention was studied over a wide variety of the equilibrium concentration values $(10-70 \mathrm{mg} / \mathrm{L})$ from the aqueous solutions of $\mathrm{pH}=7$. Figure $4 \mathrm{e}$ shows the relationship between Ceph species that adsorbed onto HAP and the corresponding concentration in an aqueous solution. The preferable Ceph sorption onto HAP was accomplished from more dilute aqueous solutions. The removal values are reduced with an increase in the concentration of Ceph, and the HAP membranes become more saturated with retained Ceph. The Ceph removal on HAP was compared with other related materials, as listed in Table 1.
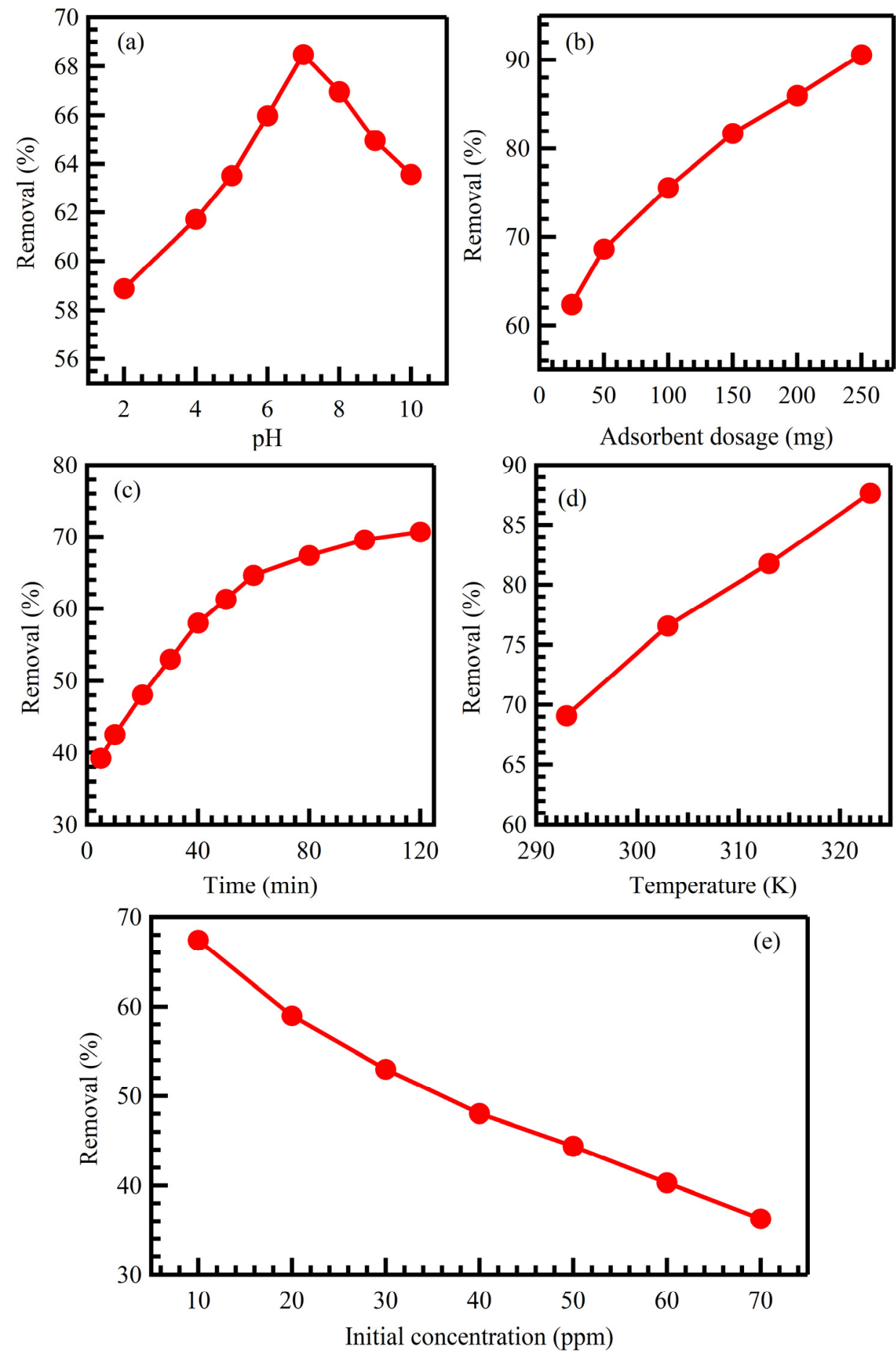

Figure 4. Effects of the solution $\mathrm{pH}(\mathbf{a})$, HAP mass (b), time (c), temperature (d), and initial concentration (e) on the adsorption percentage of Ceph from aqueous solutions onto HAP. 
Table 1. Removal efficiency comparison of Ceph on HAP with other related materials.

\begin{tabular}{|c|c|c|c|}
\hline Adsorbent & Contaminant & Removal (\%) & Ref. \\
\hline $\begin{array}{l}\text { Cerevisiae/calcium } \\
\text { alginate composite }\end{array}$ & Cephalexin & 86.23 & [48] \\
\hline $\begin{array}{l}\text { Wasted sediment (sludge } \\
\text { waste from shipping docks) }\end{array}$ & Cephalexin & $\begin{array}{c}76 \text { (urban water) } \\
63 \text { (hospital wastewater) }\end{array}$ & [49] \\
\hline Bacillus subtilis Strain & Cephalexin & $21-27$ & [50] \\
\hline Natural zeolite & Cephalexin & $\begin{array}{c}28 \\
43.52 \text { (unmodified carbon) }\end{array}$ & [51] \\
\hline $\begin{array}{l}\text { Activated carbon } \\
\text { nanoparticles }\end{array}$ & Cephalexin & $\begin{array}{l}47.65(2 \mathrm{M} \mathrm{NaCl}) \\
60.01\left(5 \mathrm{M} \mathrm{HNO}_{3}\right) \\
62.02\left(3 \mathrm{M} \mathrm{ZnCl}_{2}\right)\end{array}$ & [52] \\
\hline $\begin{array}{c}\text { Cellulose/hydroxyapatite } \\
\text { nanocomposites }\end{array}$ & $\begin{array}{l}\text { Chlortetracycline } \\
\text { hydrochloride }\end{array}$ & 70.81 & [53] \\
\hline $\begin{array}{l}\text { Hydroxyapatite and } \\
\text { aluminosilicates }\end{array}$ & Oxytetracycline & 50 & [54] \\
\hline Hydroxyapatite & Fluoroquinolone & $47.3-51.6$ & [55] \\
\hline Hydroxyapatite & Cephalexin & 70.70 & This study \\
\hline
\end{tabular}

\subsubsection{Kinetic Behavior of Ceph Sorption onto HAP}

The sorption kinetic of pollutants, for example, Ceph species from aqueous solution by solid sorbent, is a significant key since it provides important information about the reaction pathways and the mechanism of the sorption steps. Film diffusion and intraparticle diffusion regulate the general transport rate, and the faster one controls the retention of Ceph species sorption onto the solid phase HAP. From the effect of the shaking time, this conclusion was supported by calculating the half-life time $\left(\mathrm{t}_{1 / 2}\right)$ of Ceph sorption from aqueous solutions onto HAP. The $t_{1 / 2}$ values were computed from plots of $\log C / C_{o}$ vs. the time of Ceph sorption onto HAP. The value of $t_{1 / 2}$ was $1.4 \pm 0.05 \mathrm{~min}$, in agreement with values of $t_{1 / 2}$ reported earlier [56]. The kinetics of Ceph species sorption onto the HAP sorbent are affected by the film and intra-particle diffusion, controlling the total transportation rate. The sorbed Ceph species onto the sorbent underwent the WeberMorris model [57]:

$$
q_{t}=K_{d} t^{1 / 2}+C
$$

where $K_{d}$ represents the rate constant of the intraparticle diffusion and $q_{t}$ represents the sorbed Ceph concentration at time $t$. The $q_{t}$ plot vs. time is exhibited in Figure $5 \mathrm{a} . K_{d}$ and $C$ values computed from the two distinct Weber-Morris plot slopes (Figure 5a) for the Ceph were 0.24 and $0.09 \mathrm{mg} / \mathrm{g}$, respectively, with $\mathrm{R}^{2}=0.969$ correlation coefficient.

The fractional power function kinetics model may be represented by following Equation (4) [58]:

$$
\ln q_{t}=\ln a+b \ln t
$$

$q_{t}(\mathrm{mg} / \mathrm{g})$ represents the amount of Ceph species that adsorbed per HAP unit mass at any time $t$, whereas $a$ and $b$ represent coefficients. The application of the fractional power function equation to the experimental data of the adsorption process can be seen in Figure $5 \mathrm{~b}$. Data came well together with the correlation coefficient $\left(R^{2}\right)$ value 0.989 for the Ceph, and the values of $a$ and $b$ are shown in Table 2. These data can indicate that the function of the fractional power kinetics model is not suitable for the description of Ceph species adsorption by the HAP. 

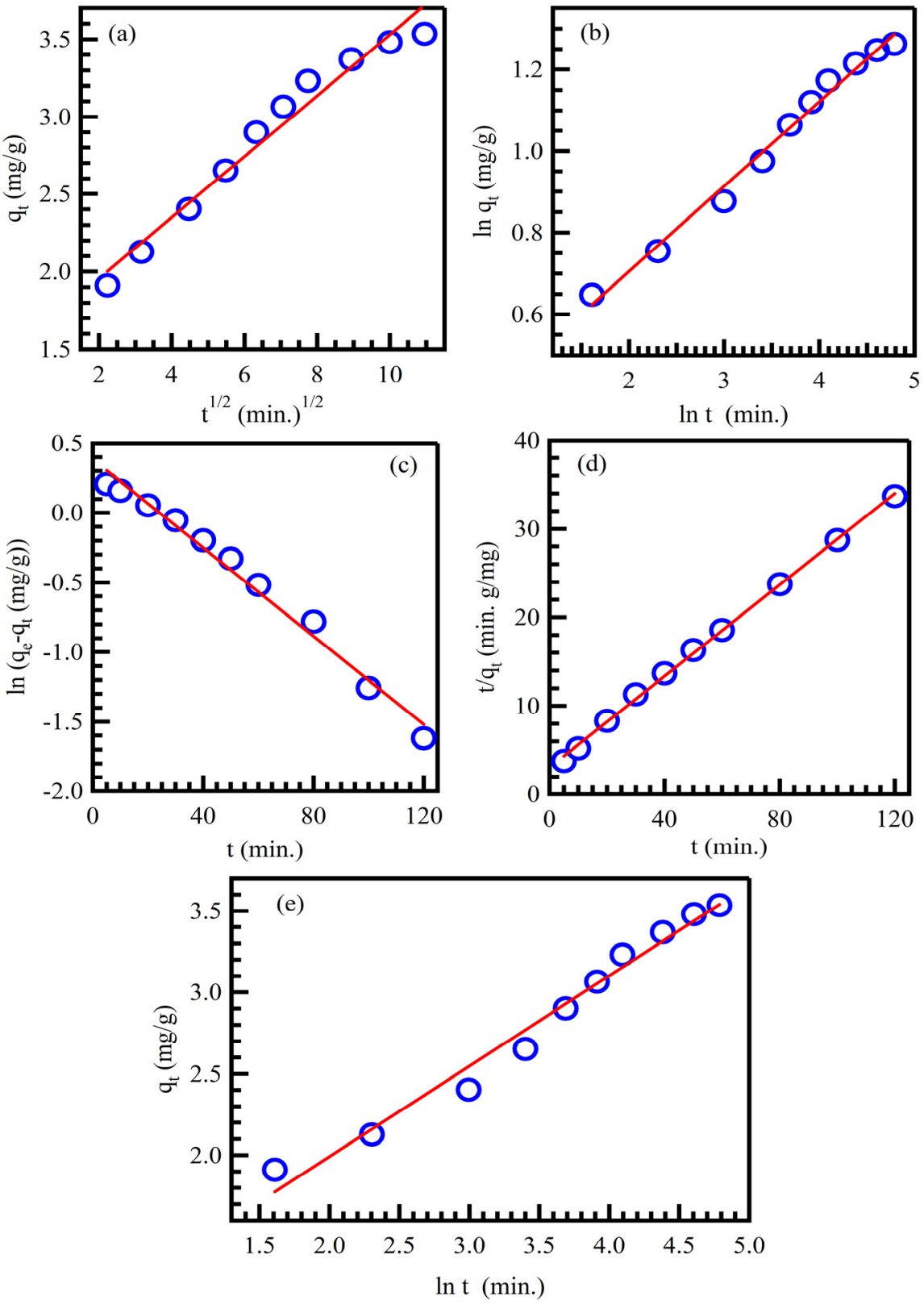

Figure 5. Weber-Morris (a), fractional power model (b), Lagergren (c), pseudo-second-order (d), and Elovich model (e) plots for Ceph uptake onto HAP.

Moreover, the Lagergren equation is a very common equation that describes the adsorption rate. The variations of Ceph species sorption from aqueous media onto the HAP solid phase were subjected to the Lagergren Equation (5) as follows [59]:

$$
\ln \left(q_{e}-q_{t}\right)=\ln q_{e}+K_{\text {Lag }} t
$$

$q_{e}$ represents the amount of the sorbed Ceph species at the equilibrium per sorbent unit mass; $K_{\text {Lag }}$ represents the first-order overall rate constant for the retention process; and $t$ represents time. The plot of $\log \left(q_{e}-q_{t}\right)$ vs. time (Figure $\left.5 c\right)$ was linear, and the calculated values of $K_{L a g}$ and $q_{e}$ were equal to $0.037 \mathrm{~min}^{-1}$ and $2.4 \mathrm{mg} / \mathrm{g}$, respectively, with the correlation coefficient $\left(R^{2}=0.985\right)$. These data do not confirm the first-order kinetics of Ceph species sorption onto the utilized solid sorbent HAP [60]. 
Table 2. Kinetic model parameters of Ceph adsorption on HAP at $293 \mathrm{~K}$.

\begin{tabular}{|c|c|c|c|c|}
\hline Model & \multicolumn{4}{|c|}{ Parameter and Value } \\
\hline \multirow{2}{*}{ Weber-Morris } & $K_{d}$ & \multicolumn{2}{|c|}{$C$} & $\mathbf{R}^{2}$ \\
\hline & 0.24 & \multicolumn{2}{|c|}{0.09} & 0.969 \\
\hline \multirow{2}{*}{ Fractional power function } & $a$ & \multicolumn{2}{|c|}{$b$} & $\mathrm{R}^{2}$ \\
\hline & 1.33 & \multicolumn{2}{|c|}{0.21} & 0.989 \\
\hline \multirow{2}{*}{$\begin{array}{l}\text { Pseudo-first-order } \\
\text { (Lagergren) }\end{array}$} & $q_{e, \exp }(\mathrm{mg} / \mathrm{g})$ & $q_{e, \text { calc }}(\mathrm{mg} / \mathrm{g})$ & $\mathrm{K}_{\text {Lag }}$ & $\mathrm{R}^{2}$ \\
\hline & 3.54 & 2.4 & 0.037 & 0.985 \\
\hline \multirow{2}{*}{ Pseudo-second-order } & $q_{e, \exp }(\mathrm{mg} / \mathrm{g})$ & $q_{e, \text { calc }}(\mathrm{mg} / \mathrm{g})$ & $\mathrm{K}_{\mathrm{S}}$ & $\mathrm{R}^{2}$ \\
\hline & 3.54 & 3.9 & $2.1 \times 10^{-2}$ & 0.999 \\
\hline \multirow{2}{*}{ Elovich } & $\alpha(\mathrm{g} / \mathrm{mg} \min )$ & \multicolumn{2}{|c|}{$\beta(\mathrm{mg} / \mathrm{g} \min )$} & $\mathrm{R}^{2}$ \\
\hline & 8.739 & \multicolumn{2}{|c|}{0.555} & 0.978 \\
\hline
\end{tabular}

In addition, the pseudo-second-order equation was interpreted, where the concentration of the adsorbate is a constant in the time, and the total number of the binding sites is dependent upon the adsorbate amount that adsorbed at the equilibrium. Equation (6) represents the linearized pseudo-second-order rate form [61-63]:

$$
\frac{t}{q t}=\frac{1}{K_{S} q_{e}^{2}}+\frac{t}{q_{e}}
$$

where $K_{S}$ is the pseudo-second-order rate of the sorption, and $q_{e}$ and $q_{t}$ represent the adsorbed amounts per unit mass at the equilibrium and at any time, respectively. Considering those circumstances, the plot of $t / q_{t}$ vs. $t$ was linear, as shown in Figure $5 d$. The equilibrium capacity $\left(q_{e}\right)$ and second-order rate constant $\left(K_{S}\right)$ for Ceph species were estimated from the slope and intercept for the Ceph as $2.1 \times 10^{-2} \mathrm{~g} / \mathrm{mg} \mathrm{min}^{-1}$ and $3.9 \mathrm{mg} / \mathrm{g}$, respectively, with perfect correlation $\left(\mathrm{R}^{2}=0.999\right)$. To double confirm the best fit of this model, MSE, RMSE, SEP, and AARD were calculated and found to be $0.110772,0.332825$, and $1.04 \%$. These low values, especially AARD (1.04\%), confirm that pseudo-second-order is the best fitting model among the applied models. All experimental data fit with sufficient values of agreement and pseudo-second-order rate constant values $\left(k_{2}\right)$, which are usually dependent upon experimental conditions such as the initial concentration of the metal, temperature, and solution $\mathrm{pH}$.

The adsorption rate also might be represented by the Elovich model, which is fundamentally applicable to the kinetics of the chemisorption and typically valid for the systems where the adsorption surface is heterogeneous as follows:

$$
q_{t}=\beta \ln (\alpha \beta)+\beta \ln t
$$

where $\alpha(\mathrm{g} / \mathrm{mg} / \mathrm{min})$ represents the initial adsorption rate, and $\beta(\mathrm{mg} / \mathrm{g} / \mathrm{min})$ represents the desorption coefficient. The plot of $q_{t}$ vs. $\ln t$ is linear in Figure 5e. Elovich parameters $\alpha$ and $\beta$ calculated from intercepts and slopes were $8.74 \mathrm{~g} / \mathrm{mg} / \mathrm{min}$ and $0.555 \mathrm{mg} / \mathrm{g} / \mathrm{min}$, respectively, with $\mathrm{R}^{2}=0.978$ for Ceph adsorbed onto HAP.

According to the above kinetic results that were utilized for fitting the adsorption of the Ceph species experimental data of fractional power function, Lagergren's pseudofirst-order, pseudo-second-order, and Elovich models and depending upon values of correlation-coefficient (shown in Table 2), it can be concluded that the pseudo-second-order kinetic model is defined as the most suitable kinetic model for the description of Ceph species adsorption on HAP from an aqueous solution. 


\subsubsection{Sorption Isotherms of Ceph onto HAP Sorbents}

Sorption isotherms were utilized to describe the Ceph interaction mechanism on the sorbent surface. According to the sorption system nature, equilibrium research is beneficial for calculating the maximal HAP sorption capacity toward Ceph, and they specify a few significant surface characteristics of the tested sorbent. The retention profiles over different equilibrium concentration values $(10-70 \mathrm{mg} / \mathrm{L})$ from aqueous Ceph solutions onto the utilized sorbent at the optimal conditions were studied.

The plot of the Ceph amount retained onto HAP vs. equilibrium concentrations of Ceph in the solution is illustrated in Figure 6a. At moderate concentration levels of the analyte, the amount of Ceph varied linearly with the Ceph remaining in the solution. A sorption capacity of $12.69 \pm 0.3 \mathrm{mg} / \mathrm{g}$ of Ceph onto HAP was achieved.
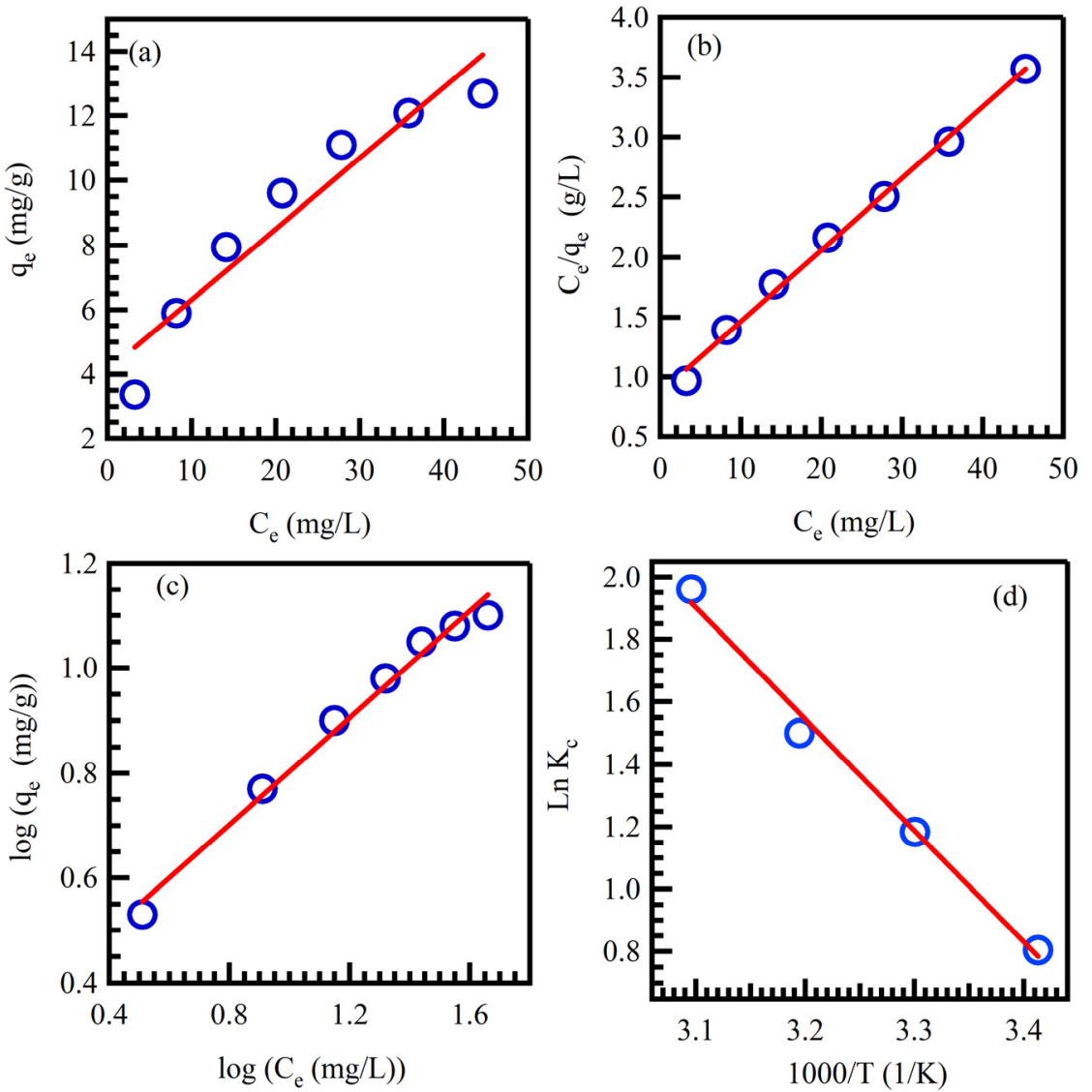

Figure 6. The plot $q_{e}$ vs. $C_{e}(\mathbf{a})$, Langmuir (b), Freundlich (c), and $\ln \mathrm{K}_{\mathrm{c}}$ vs. $1000 / \mathrm{T}$ of Ceph onto $\operatorname{HAP}(\mathbf{d})$.

The retention of Ceph onto the HAP sorbent was subjected to the Langmuir isotherm model, which is expressed in a linear form, as shown in Equation (8):

$$
\frac{C_{e}}{q_{e}}=\frac{1}{q_{\max } K_{L}}+\frac{1}{q_{\max }} C_{e}
$$

where $C_{e}$ represents the concentration of equilibrium $(\mathrm{mg} / \mathrm{L})$ of Ceph in the test solution, and $q_{e}$ represents the amount of Ceph retained to HAP per unit mass. Constant $q_{\max }$ represents the Langmuir parameter that is associated with the maximal capacity of the adsorption of the solute per unit mass of the adsorbent that is needed for the monolayer coverage of the surface, and constant $K_{L}$ represents the equilibrium constant that is associated with the binding energy of solute sorption, which does not depend on the temperature. The plot of $C_{e} / q_{e}$ vs. $C_{e}$ over the whole Ceph concentration range onto the 
HAP was linear, which may be observed from Figure $6 \mathrm{~b}$ with $\left(\mathrm{R}^{2}=0.996\right)$, which indicates that Ceph adsorption onto HAP followed the Langmuir model. Further to $\mathrm{R}^{2}$ value, the very low AARD value $(0.32 \%)$ confirmed that the Langmuir isotherm model is the best fitting model. $q_{\max }$ and $K_{L}$ values, as computed from the slope and intercept of the linear plot, were equal to $16.67 \pm 0.03 \mathrm{mmol} / \mathrm{g}$ and $0.07 \pm 0.01 \mathrm{~L} / \mathrm{mol}$, respectively.

The retention behavior of Ceph from the aqueous solution onto utilized sorbents was subjected to the Freundlich model that is expressed in the following linear form [64]:

$$
\ln q_{e}=\ln K_{F}+\frac{1}{n} \ln C_{e}
$$

where $A$ and $1 / n$ are the Freundlich parameters that are associated with the maximal capacity of sorption of the solute $(\mathrm{mg} / \mathrm{g}) ; q_{e}$ represents retained Ceph concentration onto HAP per unit mass $(\mathrm{mg} / \mathrm{g})$ at the equilibrium; and $C_{e}$ is the Ceph concentration left in aqueous solution $(\mathrm{mg} / \mathrm{L})$ (Figure 6c). The values of Freundlich's parameters computed from the intercept and the slope of Figure $6 \mathrm{c}$ were 1.95 and 0.51 . The value of $1 / n>1$ indicates the unfavorable sorption of Ceph by the HAP, and this model is most likely unsuitable for fitting well to the data.

\subsection{Thermodynamic Properties of Ceph Retention onto HAP}

The significant sorption of Ceph onto HAP was studied over different temperatures (293-323 K) to determine Ceph species retention onto HAP. The thermodynamic parameters $(\Delta S, \Delta H$, and $\Delta G)$ were assessed with the use of the following equations [65]:

$$
\begin{aligned}
\ln K_{c} & =\frac{-\Delta H}{R T}+\frac{\Delta S}{R} \\
\Delta G & =\Delta H-T \Delta S \\
\Delta G & =-R T \ln K_{c}
\end{aligned}
$$

where $\Delta S, \Delta H$, and $\Delta G$ represent entropy, enthalpy, and Gibbs free energy changes, respectively. T represents temperature in $K ; R$ represents gas constant $(\approx 8.314 \mathrm{~J} / \mathrm{K} . \mathrm{mol})$; and $K_{C}$ represents equilibrium constant. The values of $K_{C}$ for the retention of Ceph from the aqueous test solution at the equilibrium onto solid sorbent were estimated with the use of the following equation:

$$
k_{c}=\frac{C_{a}}{C_{e}}
$$

where $C_{e}$ represents the Ceph equilibrium concentration in the aqueous solution $(\mathrm{mg} / \mathrm{L})$ and $C_{a}$ represents the Ceph amount that was adsorbed onto solid-phase per liter at equilibrium (mg/L). The plot of $\ln K_{C}$ vs. 1000/T for retention of Ceph onto HAP solid phase was linear (Figure $6 \mathrm{~d}$ ) over the range of temperatures. The equilibrium constant increased with the temperature increase, revealing that the retention of Ceph onto the utilized sorbents is endothermic. The numerical $\Delta H, \Delta S$, and $\Delta G$ values for Ceph retention that were computed from the slope and intercept of the linear plot of $\ln K_{C}$ versus $1000 / T$ (Figure $6 d$ ) and found to be $29.70 \pm 0.2 \mathrm{~kJ} / \mathrm{mol}, 107.9 \pm 0.4 \mathrm{~J} / \mathrm{mol} / \mathrm{K}$, and $-1.94 \pm 0.1 \mathrm{~kJ} / \mathrm{mol}$ (at $293 \mathrm{~K})$, respectively. The positive $\Delta H$ value shows the endothermic nature of the uptake process and reflects differences in the bond energy between the analyte and sorbent. The positive value of $\Delta S$ for the solid-phase HAP suggested an increase in freedom degree at the solid-liquid interface, which is mainly encountered in the Ceph species binding due to the release of the water molecules of the water hydration sphere throughout the processes of the adsorption. The negative $\Delta G$ value at $293 \mathrm{~K}$ for the formed solid-phase implies the physical and spontaneous sorption of the Ceph species retention nature onto the HAP. 


\section{Conclusions}

The recycled eggshell was used to successfully produce HAP powders with nano-sized particles of approximately $100 \mathrm{~nm}$ using phosphate solution via a simple wet chemical precipitation approach. XRD and TEM characterized the HAP solid adsorbent. The powder produced was a high-purity ceramic calcium phosphate substance. Based on the present findings, eggshell waste material is affordable and may be a potential option for highvolume HAP powder production. The removal of Ceph species from the aqueous solutions using HAP was investigated. The impacts of the variation of the experimental parameters influencing Ceph removal/adsorption from aqueous solution by HAP such as the $\mathrm{pH}$, the HAP mass, solution temperature, contact time, and Ceph concentration were observed. Results showed that the efficiency of removing $10 \mathrm{mg} / \mathrm{L}$ of the concentration of Ceph on $50 \mathrm{mg}$ mass of HAP per $25 \mathrm{~mL}$ in $\mathrm{pH}=7$ for $60 \mathrm{~min}$ shaking time and temperature at $293 \mathrm{~K}$ was $70.70 \%$. The Ceph species adsorption kinetics by HAP was researched thoroughly using various kinetic models, and results showed that the pseudo-secondorder model is considered the most appropriate model, identified by maximum correlation coefficient values. The thermodynamic study of the removal process showed that the process of adsorption is spontaneous with the increase in the temperature of the solution, the endothermic nature with a positive entropy value, and the interaction of the Ceph species with HAP is electrostatic and physical. Based on the findings of this study, future work on this area might consider functionalization of the HAP with some groups or nanoparticles impregnations to make it more effective in metal ion capture. These HAPbased nanocomposites are promising for other antibiotics, heavy metals, and organic dye removal.

Author Contributions: Conceptualization, H.S.A. and N.A.; methodology, H.S.A., S.A.Y. and M.Y.K.; software, S.A.Y.; validation, H.S.A. and M.Y.K.; formal analysis, N.A. and M.Y.K.; investigation, H.S.A.; resources, N.A.; data curation, H.S.A., and S.A.Y.; writing-original draft preparation, H.S.A. and G.A.M.A.; writing-review and editing, H.S.A. and G.A.M.A.; visualization, G.A.M.A.; supervision, G.A.M.A.; project administration, H.S.A., S.A.Y. and G.A.M.A. All authors have read and agreed to the published version of the manuscript.

Funding: This research received no external funding. And The APC was funded by the authors themselves.

Data Availability Statement: The data presented in this study are available in the article.

Acknowledgments: The authors are grateful to the University of Hull for using XRD and TEM facilities. In addition, the authors thank the University of Dohuk for completing the experimental component, especially at the UoD PEER Project. Suhad A. Yasin thanks for the financial support provided by the USAID Partnerships for Enhanced Engagement in Research (PEER) Program. It is an international grant program that funds scientists and engineers in developing countries who collaborate with U.S. government-funded researchers to address global challenges. The program is administered by the National Academies of Sciences, Engineering, and Medicine of the United States (NASEM), PEER/Iraq project/cycle 6 .

Conflicts of Interest: The authors declare no conflict of interest.

\section{References}

1. Bound, J.P.; Kitsou, K.; Voulvoulis, N. Household disposal of pharmaceuticals and perception of risk to the environment. Environ. Toxicol. Pharmacol. 2006, 21, 301-307. [CrossRef]

2. Bilal, M.; Mehmood, S.; Rasheed, T.; Iqbal, H.M.N. Antibiotics traces in the aquatic environment: Persistence and adverse environmental impact. Curr. Opin. Environ. Sci. Health 2020, 13, 68-74. [CrossRef]

3. Afsa, S.; Hamden, K.; Martin, P.A.L.; Mansour, H.B. Occurrence of 40 pharmaceutically active compounds in hospital and urban wastewaters and their contribution to Mahdia coastal seawater contamination. Environ. Sci. Pollut. Res. 2020, 27, 1941-1955. [CrossRef]

4. Liu, H.; Liu, W.; Zhang, J.; Zhang, C.; Ren, L.; Li, Y. Removal of cephalexin from aqueous solutions by original and Cu (II)/Fe (III) impregnated activated carbons developed from lotus stalks Kinetics and equilibrium studies. J. Hazard. Mater. 2011, 185, 1528-1535. [CrossRef] 
5. Harrison, C.J.; Bratcher, D. Cephalosporins: A review. Pediatrics Rev. 2008, 29, 264. [CrossRef]

6. Bottoni, P.; Caroli, S. Presence of residues and metabolites of pharmaceuticals in environmental compartments, food commodities and workplaces: A review spanning the three-year period 2014-2016. Microchem. J. 2018, 136, 2-24. [CrossRef]

7. Sivagami, K.; Vignesh, V.J.; Srinivasan, R.; Divyapriya, G.; Nambi, I.M. Antibiotic usage, residues and resistance genes from food animals to human and environment: An Indian scenario. J. Environ. Chem. Eng. 2020, 8, 102221. [CrossRef]

8. Mirzaei, R.; Yunesian, M.; Nasseri, S.; Gholami, M.; Jalilzadeh, E.; Shoeibi, S.; Mesdaghinia, A. Occurrence and fate of most prescribed antibiotics in different water environments of Tehran, Iran. Sci. Total Environ. 2018, 619, 446-459. [CrossRef]

9. Vobecká, L.; Tichá, L.; Atanasova, A.; Slouka, Z.; Hasal, P.; Přibyl, M. Enzyme synthesis of cephalexin in continuous-flow microfluidic device in ATPS environment. Chem. Eng. J. 2020, 396, 125236. [CrossRef]

10. Seid-Mohammadi, A.; Asgarai, G.; Ghorbanian, Z.; Dargahi, A. The removal of cephalexin antibiotic in aqueous solutions by ultrasonic waves/hydrogen peroxide/nickel oxide nanoparticles (US/ $\mathrm{H}_{2} \mathrm{O}_{2} / \mathrm{NiO}$ ) hybrid process. Sep. Sci. Technol. 2020, 55, 1558-1568. [CrossRef]

11. Basturk, I.; Varank, G.; Murat-Hocaoglu, S.; Yazici-Guvenc, S.; Can-Güven, E.; Oktem-Olgun, E.E.; Canli, O. Simultaneous degradation of cephalexin, ciprofloxacin, and clarithromycin from medical laboratory wastewater by electro-Fenton process. J. Environ. Chem. Eng. 2021, 9, 104666. [CrossRef]

12. Zhao, R.; Ma, T.; Zhao, S.; Rong, H.; Tian, Y.; Zhu, G. Uniform and stable immobilization of metal-organic frameworks into chitosan matrix for enhanced tetracycline removal from water. Chem. Eng. J. 2020, 382, 122893. [CrossRef]

13. Rathi, B.S.; Kumar, P.S. Application of adsorption process for effective removal of emerging contaminants from water and wastewater. Environ. Pollut. 2021, 280, 116995. [CrossRef]

14. Naeem, H.; Ajmal, M.; Qureshi, R.B.; Muntha, S.T.; Farooq, M.; Siddiq, M. Facile synthesis of graphene oxide-silver nanocomposite for decontamination of water from multiple pollutants by adsorption, catalysis and antibacterial activity. J. Environ. Manag. 2019, 230, 199-211. [CrossRef]

15. Krasucka, P.; Pan, B.; Ok, Y.S.; Mohan, D.; Sarkar, B.; Oleszczuk, P. Engineered biochar-A sustainable solution for the removal of antibiotics from water. Chem. Eng. J. 2021, 405, 126926. [CrossRef]

16. Nazari, G.; Abolghasemi, H.; Esmaieli, M. Batch adsorption of cephalexin antibiotic from aqueous solution by walnut shell-based activated carbon. J. Taiwan Inst. Chem. Eng. 2016, 58, 357-365. [CrossRef]

17. Mohammed, A.A.; Al-Musawi, T.J.; Kareem, S.L.; Zarrabi, M.; Al-Ma'abreh, A.M. Simultaneous adsorption of tetracycline, amoxicillin, and ciprofloxacin by pistachio shell powder coated with zinc oxide nanoparticles. Arab. J. Chem. 2020, 13, 4629-4643. [CrossRef]

18. Gashtasbi, F.; Yengejeh, R.J.; Babaei, A.A. Photocatalysis assisted by activated-carbon-impregnated magnetite composite for removal of cephalexin from aqueous solution. Korean J. Chem. Eng. 2018, 35, 1726-1734. [CrossRef]

19. Fernandez-Garcia, M.; Martinez-Arias, A.; Hanson, J.C.; Rodriguez, J.A. Nanostructured oxides in chemistry: Characterization and properties. Chem. Rev. 2004, 104, 4063-4104. [CrossRef]

20. Singh, A.; Gautam, P.K.; Verma, A.; Singh, V.; Shivapriya, P.M.; Shivalkar, S.; Sahoo, A.K.; Samanta, S.K. Green synthesis of metallic nanoparticles as effective alternatives to treat antibiotics resistant bacterial infections: A review. Biotechnol. Rep. 2020, 25, e00427. [CrossRef]

21. Habeeb, O.A.; Ramesh, K.; Ali, G.A.M.; Yunus, R.M. Low-cost and eco-friendly activated carbon from modified palm kernel shell for hydrogen sulfide removal from wastewater: Adsorption and kinetic studies. Desalination Water Treat. 2017, 84, 205-214. [CrossRef]

22. Ali, G.A.M.; Habeeb, O.A.; Algarni, H.; Chong, K.F. CaO impregnated highly porous honeycomb activated carbon from agriculture waste: Symmetrical supercapacitor study. J. Mater. Sci. 2018, 54, 683-692. [CrossRef]

23. Habeeb, O.A.; Ramesh, K.; Ali, G.A.M.; Yunus, R.M. Application of response surface methodology for optimization of palm kernel shell activated carbon preparation factors for removal of $\mathrm{H}_{2} \mathrm{~S}$ from industrial wastewater. J. Teknol. 2017, 79, 1-10. [CrossRef]

24. Ummartyotin, S.; Pechyen, C. Strategies for development and implementation of bio-based materials as effective renewable resources of energy: A comprehensive review on adsorbent technology. Renew. Sustain. Energy Rev. 2016, 62, 654-664. [CrossRef]

25. Irtiseva, K.; Lapkovskis, V.; Mironovs, V.; Ozolins, J.; Thakur, V.K.; Goel, G.; Baronins, J.; Shishkin, A. Towards Next-Generation Sustainable Composites Made of Recycled Rubber, Cenospheres, and Biobinder. Polymers 2021, 13, 574. [CrossRef]

26. Sultan, M. Hydroxyapatite/polyurethane composites as promising biomaterials. Chem. Pap. 2018, 72, 2375-2395. [CrossRef]

27. Ragab, A.; Ahmed, I.; Bader, D. The removal of brilliant green dye from aqueous solution using nano hydroxyapatite/chitosan composite as a sorbent. Molecules 2019, 24, 847. [CrossRef]

28. Bee, S.-L.; Hamid, Z.A.A. Hydroxyapatite derived from food industry bio-wastes: Syntheses, properties and its potential multifunctional applications. Ceram. Int. 2020, 46, 17149-17175. [CrossRef]

29. Habeeb, O.A.; Ramesh, K.; Ali, G.A.M.; Yunus, R.M. Isothermal modelling based experimental study of dissolved hydrogen sulfide adsorption from waste water using eggshell based activated carbon. Malays. J. Anal. Sci. 2017, $21,334-345$.

30. AbdelGhany, G.S.; Ebrahiem, E.E.; Mohamed, H.F.M.; Ali, G.A.M.; Shehata, N. Eco-friendly activated carbon developed from rice hulls for chromium and iron ion removal. J. Environ. Eng. Sci. 2021, 40, 1-14. [CrossRef]

31. Moosavi, S.; Lai, C.W.; Akbarzadeh, O.; Johan, M.R. Recycled Activated Carbon-Based Materials for the Removal of Organic Pollutants from Wastewater. In Waste Recycling Technologies for Nanomaterials Manufacturing; Makhlouf, A.S.H., Ali, G.A.M., Eds.; Springer International Publishing: Cham, Switzerland, 2021; pp. 513-539. [CrossRef] 
32. Ali, G.A.M.; Makhlouf, A.S.H. Fundamentals of Waste Recycling for Nanomaterial Manufacturing. In Waste Recycling Technologies for Nanomaterials Manufacturing; Makhlouf, A.S.H., Ali, G.A.M., Eds.; Springer International Publishing: Cham, Switzerland, 2021; pp. 3-24. [CrossRef]

33. Akram, M.; Ahmed, R.; Shakir, I.; Ibrahim, W.A.W.; Hussain, R. Extracting hydroxyapatite and its precursors from natural resources. J. Mater. Sci. 2014, 49, 1461-1475. [CrossRef]

34. Esmaeilkhanian, A.; Sharifianjazi, F.; Abouchenari, A.; Rouhani, A.; Parvin, N.; Irani, M. Synthesis and characterization of natural nano-hydroxyapatite derived from turkey femur-bone waste. Appl. Biochem. Biotechnol. 2019, 189, 919-932. [CrossRef] [PubMed]

35. Ummartyotin, S.; Manuspiya, H. Eggshell waste: An effective source of hydroxyapatite for photocatalyst. J. Met. Mater. Miner. 2018, 28, 124-135.

36. Boonyang, U.; Chaopanich, P.; Wongchaisuwat, A.; Senthongkaew, P.; Siripaisarnpipat, S. Effect of phosphate precursor on the production of hydroxyapatite from crocodile eggshells. J. Biomim. Biomater. Tissue Eng. 2010, 5, 31-37. [CrossRef]

37. Kamalanathan, P.; Ramesh, S.; Bang, L.T.; Niakan, A.; Tan, C.Y.; Purbolaksono, J.; Chandran, H.; Teng, W.D. Synthesis and sintering of hydroxyapatite derived from eggshells as a calcium precursor. Ceram. Int. 2014, 40, 16349-16359. [CrossRef]

38. Chaudhuri, B.; Mondal, B.; Modak, D.K.; Pramanik, K.; Chaudhuri, B.K. Preparation and characterization of nanocrystalline hydroxyapatite from egg shell and $\mathrm{K}_{2} \mathrm{HPO}_{4}$ solution. Mater. Lett. 2013, 97, 148-150. [CrossRef]

39. Ummartyotin, S.; Tangnorawich, B. Utilization of eggshell waste as raw material for synthesis of hydroxyapatite. Colloid Polym. Sci. 2015, 293, 2477-2483. [CrossRef]

40. Sadegh, H.; Ali, G.A.M.; Agarwal, S.; Gupta, V.K. Surface Modification of MWCNTs with carboxylic-to-amine and their superb adsorption performance. Int. J. Environ. Res. 2019, 13, 523-531. [CrossRef]

41. Agarwal, S.; Sadegh, H.; Monajjemi, M.; Makhlouf, A.S.H.; Ali, G.A.M.; Memar, A.O.H.; Shahryari-ghoshekandi, R.; Tyagi, I.; Gupta, V.K. Efficient removal of toxic bromothymol blue and methylene blue from wastewater by polyvinyl alcohol. J. Mol. Liq. 2016, 218, 191-197. [CrossRef]

42. Gupta, V.K.; Agarwal, S.; Sadegh, H.; Ali, G.A.M.; Bharti, A.K.; Hamdy, A.S. Facile route synthesis of novel graphene oxide- $\beta$ cyclodextrin nanocomposite and its application as adsorbent for removal of toxic bisphenol A from the aqueous phase. J. Mol. Liq. 2017, 237, 466-472. [CrossRef]

43. Sadegh, H.; Ali, G.A.M.; Makhlouf, A.S.H.; Chong, K.F.; Alharbi, N.S.; Agarwal, S.; Gupta, V.K. MWCNTs-Fe ${ }_{3} \mathrm{O}_{4}$ nanocomposite for $\mathrm{Hg}$ (II) high adsorption efficiency. J. Mol. Liq. 2018, 258, 345-353. [CrossRef]

44. Maleki, A.; Safdari Shadloo, M.; Rahmat, A. Application of Artificial Neural Networks for Producing an Estimation of HighDensity Polyethylene. Polymers 2020, 12, 2319. [CrossRef] [PubMed]

45. Aqliliriana, C.M.; Ernee, N.M.; Irmawati, R. Preparation and characterization of modified calcium oxide from natural sources and their application in the transesterification of palm oil. Int. J. Sci. Technol. Res. 2015, 4, 168-175.

46. Kaya, I.; Şahin, M.C.; Cingöz, İ.D.; Aydin, N.; Atar, M.; KizmazoĞLu, C.; Kavuncu, S.; Aydin, H.E. Three dimensional printing and biomaterials in the repairment of bone defects; hydroxyapatite PLA filaments. Turk. J. Med. Sci. 2019, 49, 922-927. [CrossRef]

47. Dastgheib, S.A.; Rockstraw, D.A. A systematic study and proposed model of the adsorption of binary metal ion solutes in aqueous solution onto activated carbon produced from pecan shells. Carbon 2002, 40, 1853-1861. [CrossRef]

48. Rusu, L.; Grigoras, C.G.; Simion, A.I.; Suceveanu, E.M.; Șuteu, D.; Harja, M. Application of saccharomyces cerevisiae/calcium alginate composite beads for cephalexin antibiotic biosorption from aqueous solutions. Materials 2021, 14, 4728. [CrossRef]

49. Tavasol, F.; Tabatabaie, T.; Ramavandi, B.; Amiri, F. Photocatalyst production from wasted sediment and quality improvement with titanium dioxide to remove cephalexin in the presence of hydrogen peroxide and ultrasonic waves: A cost-effective technique. Chemosphere 2021, 284, 131337. [CrossRef]

50. Al-Gheethi, A.; Lalung, J.; Noman, E.; Ismail, N. Removal of cephalexin antibiotic and heavy metals from pharmaceutical effluents using Bacillus subtilis strain. Expert Opin. Environ. Biol. 2015, 4, 2.

51. Mohseni-Bandpi, A.; Al-Musawi, T.J.; Ghahramani, E.; Zarrabi, M.; Mohebi, S.; Vahed, S.A. Improvement of zeolite adsorption capacity for cephalexin by coating with magnetic Fe3O4 nanoparticles. J. Mol. Liq. 2016, 218, 615-624. [CrossRef]

52. Pouretedal, H.R.; Sadegh, N. Effective removal of amoxicillin, cephalexin, tetracycline and penicillin G from aqueous solutions using activated carbon nanoparticles prepared from vine wood. J. Water Process Eng. 2014, 1, 64-73. [CrossRef]

53. Jin, Y.; Ni, Y.; Pudukudy, M.; Zhang, H.; Wang, H.; Jia, Q.; Shan, S. Synthesis of nanocrystalline cellulose/hydroxyapatite nanocomposites for the efficient removal of chlortetracycline hydrochloride in aqueous medium. Mater. Chem. Phys. 2022, 275, 125135. [CrossRef]

54. Martínez-Olivas, A.; Torres-Pérez, J.; Balderas-Hernández, P.; Reyes-López, S.Y. Oxytetracycline Sorption onto Synthetized Materials from Hydroxyapatite and Aluminosilicates. Water Air Soil Pollut. 2020, 231, 264. [CrossRef]

55. Chen, Y.; Lan, T.; Duan, L.; Wang, F.; Zhao, B.; Zhang, S.; Wei, W. Adsorptive removal and adsorption kinetics of fluoroquinolone by nano-hydroxyapatite. PLoS ONE 2015, 10, e0145025. [CrossRef]

56. Al-Saidi, H.M.; Abdel-Fadeel, M.A.; El-Sonbati, A.Z.; El-Bindary, A.A. Multi-walled carbon nanotubes as an adsorbent material for the solid phase extraction of bismuth from aqueous media: Kinetic and thermodynamic studies and analytical applications. J. Mol. Liq. 2016, 216, 693-698. [CrossRef]

57. Campos, N.F.; Barbosa, C.M.B.M.; Rodríguez-Díaz, J.M.; Duarte, M.M.M.B. Removal of naphthenic acids using activated charcoal: Kinetic and equilibrium studies. Adsorpt. Sci. Technol. 2018, 36, 1405-1421. [CrossRef]

58. Dalal, R.C. Desorption of soil phosphate by anion-exchange resin. Commun. Soil Sci. Plant Anal. 1974, 5, 531-538. [CrossRef] 
59. Abdel Salam, M. Removal of heavy metal ions from aqueous solutions with multi-walled carbon nanotubes: Kinetic and thermodynamic studies. Int. J. Environ. Sci. Technol. 2013, 10, 677-688. [CrossRef]

60. Salam, M.A.; Lateefa, A.; Abdel-Fadeel, M.A. Removal of toxic ammonium ions from water using nanographene sheets. Desalination Water Treat. 2018, 129, 168-176. [CrossRef]

61. Sadegh, H.; Ali, G.A.M.; Nia, H.J.; Mahmoodi, Z. Nanomaterial Surface Modifications for Enhancement of the Pollutant Adsorption From Wastewater. In Nanotechnology Applications in Environmental Engineering; IGI Global: Hershey, PA, USA, $2019 ;$ p. 143.

62. Arabi, S.M.S.; Lalehloo, R.S.; Olyai, M.R.T.B.; Ali, G.A.M.; Sadegh, H. Removal of congo red azo dye from aqueous solution by ZnO nanoparticles loaded on multiwall carbon nanotubes. Phys. E Low-Dimens. Syst. Nanostructures 2019, 106, 150-155. [CrossRef]

63. Sadegh, H.; Ali, G.A.M.; Abbasi, Z.; Nadagoud, M.N. Adsorption of Ammonium Ions onto Multi-Walled Carbon Nanotubes. Studia Univ. Babes-Bolyai Chem. 2017, 62, 233-245. [CrossRef]

64. Reichenberg, D. Properties of ion-exchange resins in relation to their structure. III. Kinetics of exchange. J. Am. Chem. Soc. 1953, 75, 589-597. [CrossRef]

65. Hameed, S.A.; Abdel-Fadeel, M.A.; Al-Saidi, H.M.; Salam, M.A. Simultaneous removal of the toxic tungsten ions and rhodamine B dye by graphene nanosheets from model and real water. Desalination Water Treat. 2020, 188, 266-276. [CrossRef] 